\title{
PENGARUH KARAKTERISTIK PERUSAHAAN, KINERJA PERUSAHAAN, DAN MANAGEMENT ENTRENCHMENT TERHADAP MANAJEMEN LABA
}

\author{
Sukiantono Tang* \\ Universitas Internasional Batam, Indonesia \\ Fiorentina \\ Universitas Internasional Batam, Indonesia
}

\begin{abstract}
The purposes of this study is to investigate the impact of firm characteristics, firm performances, and management entrenchment on earnings management by using firms registered on Bursa Efek Indonesia for the period 2015-2019. Sampling method that is used in this study is purposive sampling method so the objects should meet the criteria. The exception sample for this study is financial firms due to differences on some regulations of reporting and firms without complete annual and financial report published for the period 2015-2019. The secondary data were obtained from firms' financial report and annual report that were published on the firms' official website and Bursa Efek Indonesia's website. In this study, earnings management is measured with Modified Jones Model. This study analyzed using fixed effect model approach panel data regression analysis. The results show that growth opportunities, board size, current ratio, auditor size, financial statement, and CEO ownership have no significant influences. Leverage, firm size, asset growth and turnover, and cash flow show significant negative influences. On the other hand, long-term and short-term debts, and CEO tenure show significant positive influences. Some results are not compatible with hypothesis since there are limitations on the period time and methods that were chosen.
\end{abstract}

JEL : M410, M480

Keywords : earnings management, firm characteristics, firm performances, management entrenchment.

\begin{abstract}
ABSTRAK
Penelitian ini dilakukan dengan tujuan untuk meneliti adanya pengaruh dari karakteristik perusahaan, kinerja perusahaan, dan management entrenchment terhadap manajemen laba dengan menggunakan perusahaan yang terdaftar di Bursa Efek Indonesia periode 2015-2019. Metode pengambilan sampel yang digunakan dalam penelitian ini adalah metode purposive sampling sehingga objek penelitian harus sesuai dengan kriteria. Sampel data yang dikecualikan adalah perusahaan keuangan atau finansial karena memiliki regulasi pelaporan yang berbeda dan perusahaan yang tidak memiliki kelengkapan laporan keuangan dan laporan tahunan periode 2015-2019. Data sekunder diperoleh dari laporan keuangan dan laporan tahunan perusahaan yang dipublikasikan pada website resmi perusahaan dan website Bursa Efek Indonesia. Dalam penelitian ini, manajemen laba diukur dengan Modified Jones Model. Penelitian ini dianalisis menggunakan analisis regresi data panel dengan pendekatan fixed effect model. Hasil pengujian menunjukan bahwa peluang pertumbuhan, ukuran dewan direktur, rasio lancar, ukuran auditor, laporan keuangan, dan kepemilikan direktur utama tidak memiliki pengaruh signifikan. Sedangkan leverage, ukuran perusahaan, pertumbuhan dan perputaran aset, dan arus kas operasional memiliki pengaruh signifikan negatif terhadap manajemen laba. Utang jangka panjang dan pendek, serta masa jabatan direktur memiliki pengaruh signifikan positif. Hasil pengujian yang tidak sesuai dengan hipotesis dapat disebabkan karena adanya keterbatasan dalam periode waktu dan metode pengukuran yang digunakan.
\end{abstract}

Kata Kunci : manajemen laba, karakteristik perusahaan, kinerja perusahaan, management entrenchment.

*Email : sukiantono.tang@gmail.com

Received : 20-06-2021, Accepted: 20-08-2021, Published : 29-08-2021

P-ISSN : 2087-9954, E-ISSN : 2550-0066. DOI : http://dx.doi.org/10.26418/jebik.v10i2.47461 


\section{PENDAHULUAN}

Semakin maraknya dunia investasi di kalangan masyarakat mendorong tinggi kepentingan laporan keuangan yang dipublikasikan oleh perusahaan. Laporan keuangan adalah sumber informasi mengenai kondisi dan kinerja perusahaan baik untuk pengguna eksternal maupun pengguna informasi seperti pemegang saham dan kreditur (Adi, Putri, \& Permatasari, 2020). Laporan keuangan seharusnya merupakan sumber informasi yang terpercaya dan dapat diandalkan karena akan digunakan sebagai analisis kinerja perusahan. Namun hingga saat ini, tidak sedikit kasus atau berita terkait perusahaan yang telah mengubah informasi kinerja ekonomi perusahaan demi dinilai sebagai perusahaan memiliki kinerja yang baik.

Kinerja perusahaan yang baik dapat ditampilkan melalui angka dalam laporan keuangan sehingga pengguna laporan keuangan dapat menilai perusahaan dengan melakukan perbandingan kinerja perusahaan dengan pesaing lainnya. Dikarenakan kepentingan atas laporan keuangan perusahaan, maka manajer selaku operator perusahaan akan berusaha untuk merancang strategi dalam meningkatkan kualitas laporan keuangan. Namun, ketika laporan perusahaan menunjukan bahwa perusahaan mengalami penurunan kinerja yang dapat menyebabkan menurunnya nilai perusahaan, manajer mendapat motivasi untuk melakukan kecurangan dengan mengubah informasi yang tidak sebenarnya terjadi. Penipuan atas informasi keuangan ini dikenal sebagai sebutan manajemen laba. Manajemen laba adalah tindakan yang dilakukan oleh pihak manajemen perusahaan yang mencoba untuk menyesatkan pemangku kepentingan mengenai kinerja keuangan perusahaan (Qawasmeh \& Azzam, 2020). Manajemen laba dapat dilakukan dengan dua teknik yaitu manajemen berbasis akrual dan manajemen laba riil dimana yang berbeda pada cara manipulasinya. Manajemen laba berbasis akrual dilakukan dengan mengubah prinsip akuntansi ketika dalam tahap mempersiapkan laporan keuangan untuk dipublikasikan sedangkan manajemen laba riil dilakukan pada aktivitas sehari-hari dalam perusahaan dan dapat dilakukan setiap saat (Adi et al., 2020). Manajemen laba muncul pertama kali di Indonesia ketika krisis ekonomi pada tahun 1997 dengan adanya kasus berkaitan dengan perusahaan BUMN yang seharusnya menjadi pedoman bagi perusahaan lain untuk menjalankan bisnisnya.

Awal tahun 2019, ditemukan adanya perusahaan BUMN yang melakukan manipulasi laba yaitu PT Garuda Indonesia (Persero) Tbk yang melaporkan informasi tidak benar pada laporan keuangan tahun 2018. Hal tersebut terpampang jelas ketika laporan keuangan kuartal satu hingga tiga, perusahaan mengalami kerugian. Namun, pada kuartal empat perusahaan berhasil membukukan laba bersih sebesar 11,56 miliar rupiah (Arieza, 2019). Kasus ini terjadi ketika pihak manajemen perusahaan mengakui pendapatan lainnya yang seharusnya belum dapat diakui sebagai pendapatan sehingga dapat disimpulkan manajer perusahaan mengubah informasi akuntansi pada laporan keuangan. Perlakuan ini termasuk teknik manajemen laba berbasis akrual yang mengubah cara atau metode pengakuan pendapatan pada laporan keuangan. Motivasi dibalik penipuan ini dipicu oleh kerugian pada tiga kuartal pertama yang dipandang dapat menurunkan nilai perusahaan sehingga manajer perusahaan berusaha menutupi kerugian tersebut dengan melakukan manajemen laba. Maka hal ini menunjukan bahwa peningkatan nilai perusahaan dianggap sebagai tujuan utama dari manajemen.

Nilai perusahaan dapat ditingkatkan dengan adanya peningkatan dari kinerja perusahaan seperti menurunkan tingkat utang pinjaman agar resiko likuiditas rendah. Selain kinerja perusahaan, nilai perusahaan juga dapat ditingkatkan dengan karakteristik perusahaan yang baik seperti penggunaan auditor eksternal terpercaya agar terjamin akan kualitas audit laporan keuangan 
perusahaan. Karakteristik perusahaan didefinisikan sebagai kelebihan yang dinikmati oleh perusahaan dibanding pesaing lain sehingga dapat dinilai penting oleh pengguna informasi ketika analisis laporan perusahaan. Selain dari kedua faktor tersebut, manajer selaku agen menjalankan segala aktivitas bisnis perusahaan atas nama pemegang saham supaya dapat mencapai tujuan atau target bersama demi meningkatkan nilai perusahaan. Tujuan dari pencapaian tersebut ditampilkan melalui laba yang menunjukan pendapatan bersih atau neto perusahaan untuk suatu periode tertentu seperti yang ditampilkan pada laporan keuangan kuartal dan tahunan (Tulcanaza-Prieto, Lee, \& Koo, 2020). Nilai laba pada laporan keuangan menjadi patokan nilai saham perusahaan di masa depan yang dapat menarik perhatian pemegang saham, sehingga manajemen perusahaan menilai pentingnya laporan keuangan yang menunjukan angka laba dan peningkatan daripada periode sebelumnya.

Laporan keuangan yang mengalami penurunan laba akan memicu manajer untuk berusaha menampilkan laporan yang baik walaupun dengan cara tercelah seperti manajemen laba. Manajer yang seharusnya memberikan keuntungan bagi para pemegang saham, justru menyalahgunakan wewenangnya sebagai operator demi kepentingan pribadi. Dengan manipulasi tersebut, manajer dapat mempertahankan posisinya dan juga mendapatkan imbalan seperti komisi jika perusahaan mengalami peningkatan laba. Perlakuan yang menyalahgunakan kekuasaan dari manajer ini sering kali disebut sebagai management entrenchment (Fagbemi, Osemene, \& Agbaje, 2020). Entrenchment dari seorang manajer memberikannya hak untuk merancang, menjalankan dan mengejar hasil yang dapat menguntungkan perusahaan (Fagbemi et al., 2020). Hak tersebut diberikan oleh pemegang saham bagi manajemen untuk mengejar tujuan atau target yang diinginkan agar mendapatkan keuntungan seperti dividen yang tinggi. Dengan kekuasaan tersebut, manajer dapat melakukan manipulasi pada laporan keuangan ketika tujuan yang dirancang tidak tercapai dengan mengubah informasi keuangan periode tertentu.

Penelitian ini melibatkan tiga unsur penting dalam perusahaan, yaitu karakteristik perusahaan, kinerja perusahaan, dan management entrenchment. Karakteristik perusahaan melibatkan banyak variabel dalam penelitian supaya dapat meningkatkan persentase keakuratan akan pengaruh faktor tersebut terhadap potensi terjadinya manajemen laba. Seperti penelitian Bassiouny (2018) yang meneliti karakteristik perusahaan dengan hanya beberapa variabel umum menghasilkan tidak adanya pengaruh signifikan terhadap manajemen laba. Fagbemi et al. (2020) meneliti pengaruh dari karakteristik perusahaan menunjukan adanya pengaruh signifikan positif terhadap manajemen laba, namun Edi \& Jessica (2020) menghasilkan adanya pengaruh signifikan negatif. Sehingga untuk memperkaya hasil penelitian ini, beberapa variabel seperti perputaran dan pertumbuhan aset, rasio lancar, dan tipe laporan keuangan ditambahkan supaya meningkatkan keakuratan pengaruh terhadap manajemen laba. Untuk mempertajam hasil, kinerja perusahaan juga perlu dipertimbangkan sebagai faktor pemicu terjadinya manajemen laba seperti penelitian Fung \& Goodwin (2013) dan Trung, Liem, \& Thuy (2020) yang menemukan pengaruh signifikan positif dari utang jangka pendek terhadap manajemen laba. Namun, penelitian ini menambahkan arus kas operasional supaya mendukung perputaran kas perusahaan yang berkaitan dengan perputaran aset pada karakteristik perusahaan. Selain itu, management entrenchment yang diteliti oleh Fagbemi et al. (2020) menunjukan bahwa hasil yang tidak signifikan dari kepemilikan saham manajerial sedangkan adanya pengaruh signifikan positif dari masa jabatan CEO. Management entrenchment jarang diteliti sehingga dapat dijadikan unsur baru dalam penelitian ini. 


\section{KAJIAN LITERATUR}

\subsection{Manajemen Laba}

Manajemen laba diterapkan oleh manajer dengan berbagai motivasi yang dapat menguntungkan perusahaan ataupun pribadi. Manajer memiliki kekuasaan untuk melakukan hal tersebut dikarenakan peran khususnya dalam organisasi untuk mengatur operasional dan membuat perjanjian dengan tujuan mencapai kesepakatan paling baik di antara setiap alternatif (Fagbemi et al., 2020). Dengan peran penting maka manajer telah mendapatkan kekuasaan secara tidak langsung dari pemegang saham untuk menjalankan perusahaan. Kekuasaan tersebut seringkali dipersalahgunakan oleh manajer untuk mencapai tujuan pribadi bukan tujuan bersama didukung dengan berbagai motivasi seperti komisi, bonus, ataupun kesusahan pribadi. Bassiouny (2018) mengutip bahwa munculnya manajemen laba berasal dari penerapan akuntansi berbasis akrual pada arus kas yang memudahkan manajemen untuk memanipulasi informasi keuangan akrual dikarenakan kurang dapat diamati.

Manajemen laba menggunakan proksi discretionary accruals sesuai pada metode model perhitungan dari Modified Jones Model yang diteliti oleh Dechow, Sloan, \& Sweeney (1995) dikarenakan pada rumus ini ada menggunakan perubahan piutang pelanggan yang dapat menghapuskan pengaruh dari laba akrual yang bisa saja disebabkan oleh peningkatan piutang pada periode tersebut. Sehingga perubahan laba akan lebih akurat dan menampilkan lingkup bisnis perusahaan pada tahun tersebut (Cuong \& Ha, 2018).

\subsection{Peluang Pertumbuhan Perusahaan terhadap Manajemen Laba}

Peluang pertumbuhan dijadikan sebagai penentu prospek perusahaan dalam perkembangannya sehingga perusahaan membutuhkan dana yang besar dari hasil investasi pemegang saham untuk mendanai operasionalnya (Putri \& Panggabean, 2020). Peluang pertumbuhan perusahaan dibuktikan memiliki hubungan positif terhadap manajemen laba berdasarkan penelitian Debnath (2017) dan Fung \& Goodwin (2013). Hubungan tersebut menunjukan bahwa ketika perusahaan mengalami pertumbuhan bisa saja diakibatkan oleh pemilihan akuntasi oleh manajemen dalam melaporkan nilai keuntungan perusahaan.

Alhmood, Shaari, \& Al-dhamari (2020) menemukan hubungan negatif dari kedua variabel dimana perusahaan yang memiliki peluang pertumbuhan rendah maka manajemen cenderung akan mengambil keputusan atas perlakuan manipulasi agar angka yang dilaporkan menunjukan perusahaan memiliki kinerja ekonomi yang sehat. Ada pula penelitian yang menemukan bahwa peluang pertumbuhan justru mempengaruhi secara signifikan positif terhadap manajemen laba sehingga ketika peluang pertumbuhan perusahaan tinggi dapat disebabkan oleh adanya perlakuan manajemen laba (Debnath, 2017; Trung et al., 2020).

$\mathrm{H}_{01}$ : Peluang pertumbuhan memiliki pengaruh signifikan positif terhadap manajemen laba.

\subsection{Leverage dan Manajemen Laba}

Leverage dapat menunjukan risiko yang dihadapi oleh perusahaan dimana semakin tinggi resiko maka semakin meningkat ketidakpastian perusahaan untuk menghasilkan laba di masa depan (Agustia, 2013). Sehingga ketika perusahaan sedang mengalami ketidakpastian untuk menghasilkan labanya, maka manajemen akan berusaha untuk memanipulasi laba pada laporan keuangan perusahaan agar dari mata masyarakat perusahaan masih menghasilkan laba dan bagi 
para investor masih berani untuk membeli saham dari perusahaan tersebut agar modal bagi perusahaan dapat meningkat.

Waweru \& Riro (2013) menemukan adanya hubungan signifikan positif terhadap manajemen laba yang dimana ketika leverage perusahaan menunjukan resiko yang tinggi maka dapat memicu manajemen untuk mengubah informasi yang sebenarnya pada laporan keuangan. Hal ini didukung pula oleh penelitian Asim \& Ismail (2019), Ghazali, Shafie, \& Sanusi (2015), Mahawyahrti \& Budiasih (2017), dan Bassiouny (2018).

$\mathrm{H}_{02}$ : Leverage berpengaruh signifikan positif terhadap manajemen laba.

\subsection{Ukuran Dewan Direktur dan Manajemen Laba}

Pada umumnya, ketika jumlah dewan direktur meningkat maka diperkirakan adanya pengurangan discretionary accruals dan meningkatkan kualitas laporan keuangan yang dikarenakan oleh meningkatnya tingkat pemeriksaan dan pengawasan oleh dewan direktur (Kankanamage, 2016). Ukuran dewan direktur dianggap sebagai elemen penting yang dapat mempengaruhi manajemen laba dikarenakan merupakan faktor penting untuk menentukan keefektifan dewan (Daghsni, Zouhayer, \& Mbarek, 2016). Ukuran dewan telah diteliti oleh banyak peneliti yang membuahkan hasil hubungan ukuran dewan terhadap manajemen laba adalah signfikan positif seperti penelitian Kankanamage (2016), namun ada juga signifikan negatif seperti penelitian Hung et al. (2018) dan Surya (2017). Serta ada pula penelitian yang menunjukan hubungan tidak signifikan yaitu penelitian Edi \& Jessica (2020).

$\mathrm{H}_{03}$ : Ukuran dewan direktur berpengaruh signifikan negatif terhadap manajemen laba.

\subsection{Ukuran Perusahaan dan Manajemen Laba}

Perusahaan besar memiliki perlakuan akuntansi yang lebih banyak untuk transaksi dan aset lancar. Perusahaan yang besar dapat dikatakan memiliki kemampuan untuk mengatur pendapatan perusahaannya lebih tinggi dibandingkan dengan perusahaan kecil. Namun, perusahaan besar berusaha memanipulasi laba supaya dapat mengurangi biaya politik seperti pajak (Ali, Khurshid, \& Mahmood, 2015).

Beberapa penelitian terdahulu menemukan adanya pengaruh signifikan negatif antara ukuran perusahaan dan manajemen laba seperti Cuong \& Ha (2018), Swastika (2013), Jang \& Kim (2017), dan Qawasmeh \& Azzam (2020). Ketika perusahaan memiliki ukuran yang besar maka memiliki sistem pengendalian internal yang lebih memadai, menggunakan auditor berkompeten dan memiliki reputasi yang baik sehingga lebih memiliki kemungkinan untuk menghindari perlakuan manajemen laba (Swastika, 2013). Namun ada juga penelitian seperti Ali et al. (2015), Fagbemi et al. (2020), dan Uwuigbe, Ranti, \& Bernard (2015) yang menemukan hubungan negatif dari kedua variabel dimana hal ini menandakan bahwa perusahaan besar memiliki tekanan pasar, kekuatan negosiasi lebih tinggi sehingga lebih memungkinkan dalam melakukan manipulasi.

$\mathrm{H}_{04}$ : Ukuran perusahaan berpengaruh signifikan negatif terhadap manajemen laba.

\subsection{Rasio Lancar dan Manajemen Laba}

Rasio lancar merupakan jenis rasio likuiditas yang dapat mengukur kemampuan perusahaan untuk melunaskan utang jangka pendeknya tepat waktu dengan aset lancar yang dimiliki perusahaan (Adi et al., 2020). Semakin tinggi hasil rasio ini maka kemampuan perusahaan 
untuk membayarkan utang jangka pendeknya pada tepat waktu semakin meningkat. Berbagai penelitian juga menggunakan rasio lancar sebagai penentuan likuiditas dari suatu perusahaan.

Adi et al., (2020), Cuong \& Ha (2018), Dong (2016), dan Tulcanaza-Prieto et al. (2020) menggunakan rasio lancar sebagai rasio likuiditas perusahaan dan menemukan hasil uji yang berbeda. Cuong \& Ha (2018) dan Tulcanaza-Prieto et al. (2020) menemukan adanya pengaruh signifikan negatif dari rasio lancar terhadap manajemen laba yang menyimpulkan bahwa perusahaan dengan kemampuan melunaskan utang jangka pendek tinggi tidak memotivasikan manajemen untuk melakukan manipulasi. Namun, hal tersebut bertentangan dengan Dong (2016) yang menemukan adanya pengaruh signifikan positif antara kedua varibael tersebut.

$\mathrm{H}_{05}$ : Rasio lancar berpengaruh signifikan negatif terhadap manajemen laba.

\subsection{Pertumbuhan Aset dan Manajemen Laba}

Pertumbuhan aset merupakan suatu indikator bagi perusahaan untuk menyatakan pertumbuhan perusahaan tersebut dimana perusahaan dapat mempertahankan kelangsungan usaha operasionalnya (Hapsoro \& Annisa, 2017). Pertumbuhan aset yang semakin tinggi maka dapat dikatakan perusahaan memiliki kemampuan untuk mempertahankan kelangsungan operasionalnya lebih baik dibanding periode sebelumnya. Ketika masyarakat, investor maupun pemerintah melihat perusahaan memiliki pertumbuhan yang bagus maka akan dinilai sebagai perusahaan yang dapat dipercayai atas kelangsungannya dengan perbandingan periode sebelumnya sehingga perusahaan berusaha untuk meningkatkan pertumbuhan asetnya. Penelitian Cuong \& Ha (2018), Hapsoro \& Annisa (2017), dan Jang \& Kim (2017) menemukan adanya hubungan signifikan positif diantara variabel pertumbuhan aset dan manajemen laba. Dimana ketika rasio pertumbuhan aset tinggi maka manajer akan berpotensi untuk melakukan manajemen laba dikarenakan semakin tinggi rasio ini, maka semakin mengecil pertumbuhan aset suatu perusahaan.

$\mathrm{H}_{06}$ : Pertumbuhan aset berpengaruh signifikan positif terhadap manajemen laba.

\subsection{Perputaran Aset dan Manajemen Laba}

Kemampuan perusahaan untuk menggunakan seluruh asetnya dalam menghasilkan penjualan dapat ditunjukan melalui rasio perputaran aset (Adi et al., 2020). Rasio ini biasanya digunakan sebagai indikator keefektifan aset yang digunakan dapat menghasilkan penjualan didasari dengan perhitungan dari perputaran aset ini. Jika rasio ini meningkat maka jumlah volume penjualan hampir setara jumlah aset sehingga semakin efektif perusahaan menggunakan aset untuk menghasilkan penjualan yang semakin banyak.

Adi et al. (2020) menemukan bahwa ketika perputaran aset tinggi, hal tersebut disebabkan oleh pihak manajemen yang mengubah angka penjualan menjadi semakin tinggi namun dengan jumlah aset yang sama. Namun, penemuan tersebut bertentangan dengan penelitian Cuong \& Ha (2018) dan Dong (2016) yang menemukan adanya pengaruh signifikan negatif dari perputaran aset pada manajemen laba. Sehingga ketika perusahaan memiliki perputaran aset yang tinggi maka tingkat efisiensi penggunaan aset tersebut tidak meningkatkan potensi terjadinya manajemen laba.

$\mathrm{H}_{07}$ : Perputaran aset berpengaruh signifikan negatif terhadap manajemen laba.

\subsection{Ukuran Auditor dan Manajemen Laba}

Ukuran auditor independen dalam perusahaan dapat dijadikan sebagai patokan kualitas audit perusahaan tersebut (Edi \& Jessica, 2020). Oleh karena itu, berbagai peneliti yang 
berargumentasi dalam menentukan ukuran auditor berdasarkan kantor akuntan publik yang bekerja sama dengan BIG 4 atau 4 kantor akuntan publik terkenal (KPMG, EY, Deloitte \& PwC). Penelitian sebelumnya ada yang menyimpulkan bahwa ukuran auditor dapat menurunkan potensi manajemen laba jika diaudit oleh BIG 4 dengan proses audit yang tepat dan ilmiah yang melakukan berbagai prosedur audit dalam pendeteksian kesalahan material seperti fraud dan error (Hung et al., 2018).

Pada penelitian Hung et al. (2018) yang meneliti hubungan dari ukuran auditor terhadap manajemen laba dengan tiga pengukuran modified jones model yang berbeda, ukuran auditor berpengaruh signifikan negatif terhadap manajemen laba dengan pengukuran Dechow et al. (1995). Hasil penelitian ini didukung oleh penelitian Dong (2016), Swastika (2013), dan Edi \& Jessica (2020). Namun, Gunawan, Darmawan, \& Purnamawati (2015) dan Hapsoro \& Annisa (2017) menemukan pengaruh signifikan positif antara kedua variabel yang menunjukan bahwa walaupun perusahaan menggunakan kantor akuntan publik berafiliasi dengan BIG 4 tidak menjamin dapat menekan potensi terjadinya manipulasi laba.

$\mathrm{H}_{08}$ : Ukuran auditor berpengaruh signifikan negatif terhadap manajemen laba.

\subsection{Laporan Keuangan dan Manajemen Laba}

Perusahaan yang memiliki laporan keuangan konsolidasian berarti memiliki beberapa transaksi yang akan dilakukan offset ketika menggabungkan laporan keuangan entitas induk dan entitas anak. Sehingga ketika perlakuan offset dilakukan maka dipercaya bahwa adanya potensi perlakuan manipulasi yang lebih tinggi karena semakin rumitnya dalam menyiapkan laporan keuangan konsolidasian daripada laporan keuangan tidak konsolidasi. Hal ini didapatkan dari penelitian Hung et al. (2018) yang menemukan hasil signifikan positif antara laporan keuangan konsolidasian dengan manajemen laba akrual karena manajemen laba akrual biasanya dilakukan oleh manajemen berdasarkan teknik rumit dalam menyiapkan laporan keuangan perusahaan. Hasil ini didukung oleh penelitian Dang, Hoang, \& Tran (2017). Variabel ini jarang digunakan dalam penelitian karena mayoritas perusahaan menggunakan laporan konsolidasi sehingga tidak diperhatikan bahwa adanya pengaruh dari tipe laporan keuangannya sebagai pemicu.

$\mathrm{H}_{09}$ : Laporan keuangan berpengaruh signifikan positif terhadap manajemen laba.

\subsection{Arus Kas Operasional dan Manajemen Laba}

Arus kas operasional merupakan indikator keuangan bagi investor ataupun masyarakat untuk menilai apakah suatu perusahaan yang melakukan kegiatan operasional menghasilkan laba atau rugi. Arus kas operasional jarang digunakan oleh penelitian karena laporan keuangan kebanyakan dinilai secara keseluruhan dengan gabungan arus kas lainnya sehingga perusahaan bisa menggunakan rincian kecil seperti ini untuk melakukan manipulasi. Park (2016), Cuong \& Ha (2018), Hapsoro \& Annisa (2017), dan Jang \& Kim (2017) menemukan adanya pengaruh signifikan negatif dari kedua variabel tersebut. Hal ini menunjukan bahwa ketika perusahaan memiliki arus kas operasional negatif atau minus maka dapat meningkatkan perlakuan manajemen laba.

$\mathrm{H}_{10}$ : Arus kas operasional berpengaruh signifikan negatif terhadap manajemen laba. 


\subsection{Utang Jangka Panjang dan Manajemen Laba}

Semakin banyak utang yang dimiliki oleh perusahaan maka dapat diasumsikan perusahaan mungkin saja mengalami financial distress (Christiawan \& Rahmiati, 2015). Maka dari itu, ketika perusahaan berada dalam kondisi memiliki utang yang tinggi, manajer akan termotivasi untuk melakukan manipulasi pada angka utang jangka panjang agar dapat menurunkan angka utang dan terlihat bahwa perusahaan tidak berada pada kondisi financial distress atau memiliki pinjaman yang banyak untuk menutupi biaya operasional maupun non-operasional perusahaan.

Pernyataan tersebut didukung oleh Christiawan \& Rahmiati (2015) dan Tulcanaza-Prieto et al. (2020) yang menemukan hasil signifikan positif pada penelitiannya. Sehingga perusahaan akan berusaha menutupi kenyataan atas tingginya tingkat pinjaman tersebut. Namun, ada pula penelitian yang menunjukan bahwa utang jangka panjang tidak dapat mempengaruhi potensi terjadinya perlakuan manipulasi ini yaitu penelitian oleh Cuong \& Ha (2018).

$\mathrm{H}_{11}$ : Utang jangka panjang berpengaruh signifikan positif terhadap manajemen laba.

\subsection{Utang Jangka Pendek dan Manajemen Laba}

Utang jangka pendek yang tinggi dapat mempengaruhi pada peningkatan risiko likuiditas perusahaan sehingga perusahaan dengan kelayakan kredit yang tinggi lebih diuntungkan dalam hal tersebut (Trung et al., 2020). Maka tidak jauh berbeda dengan utang jangka panjang dimana ketika perusahaan yang memiliki tingkat utang tinggi menampilkan kinerja perusahaan yang tidak baik sehingga pada penelitian Fung \& Goodwin (2013), Park (2016), dan Trung et al. (2020) ditemukan bahwa utang jangka pendek berpengaruh signifikan positif terhadap manajemen laba. Hal ini menunjukan bahwa semakin tinggi tingkat utang jangka pendek maka semakin tinggi pula potensi terjadinya manajemen laba.

$\mathrm{H}_{12}$ : Utang jangka pendek berpengaruh signifikan positif terhadap manajemen laba.

\subsection{Masa Jabatan Direktur Utama dan Manajemen Laba}

Masa jabatan seorang direktur utama dapat mempengaruhi potensi terjadinya manajemen laba melalui jumlah tahun dia bekerja pada posisi direktur utama. Direktur utama adalah suatu jabatan yang bisa dikatakan tinggi dalam suatu perusahaan sehingga dapat memicu karyawan untuk mencapai jabatan tersebut. Menurut penelitian Hu et al. (2015) yang meneliti efek dari masa jabatan direktur utama pada manajemen laba menemukan bahwa adanya manajer yang berhati-hati ketika awal mereka menjabat posisi tinggi dalam manajemen, dan kemudian setelah berjalannya tahun mereka akan menjadi agresif. Ketika mereka telah mencapai manipulasi laba pada tingkat tertinggi, maka mereka akan kembali berhati-hati dan melaporkan pendapatan yang tidak agresif seperti sebelumnya. Hal tersebut didukung dengan penelitian Fagbemi et al. (2020) dan Qawasmeh \& Azzam (2020) yang menemukan pengaruh signfikan positif dari masa jabatan direktur utama terhadap manajemen laba. Namun Alhmood et al. (2020) dan Park (2016) menemukan bahwa masa jabatan seorang direktur utama tidak dapat mempengaruhi potensi terjadinya manajemen laba baik direktur utama tersebut telah lama menjabat ataupun baru menjabat.

$\mathrm{H}_{13}$ : Masa jabatan direktur utama berpengaruh signifikan positif terhadap manajemen laba.

\subsection{Kepemilikan Direktur Utama dan Manajemen Laba}

Kepemilikan direktur utama merupakan faktor yang dapat mempengaruhi kemampuan direktur utama untuk memanipulasi laba yang dilaporkan oleh perusahaan (Qawasmeh \& Azzam, 
2020). Semakin meningkatnya saham yang dimiliki oleh direktur utama, maka semakin tinggi potensi akan terjadinya manajemen laba. Hal tersebut telah diteliti dan dibuktikan dari berbagai penelitian dengan adanya hubungan signifikan positif dari variabel kepemilikan direktur utama terhadap manajemen laba seperti penelitian Aygun \& Sayim (2014) dan Qawasmeh \& Azzam (2020). Namun, ada juga penelitian yang menunjukan bahwa tidak ada pengaruh dari persentase kepemilikan direktur utama pada manajemen laba seperti penelitian Agustia (2013).

$\mathrm{H}_{14}$ : Kepemilikan direktur utama berpengaruh signifikan positif terhadap manajemen laba.

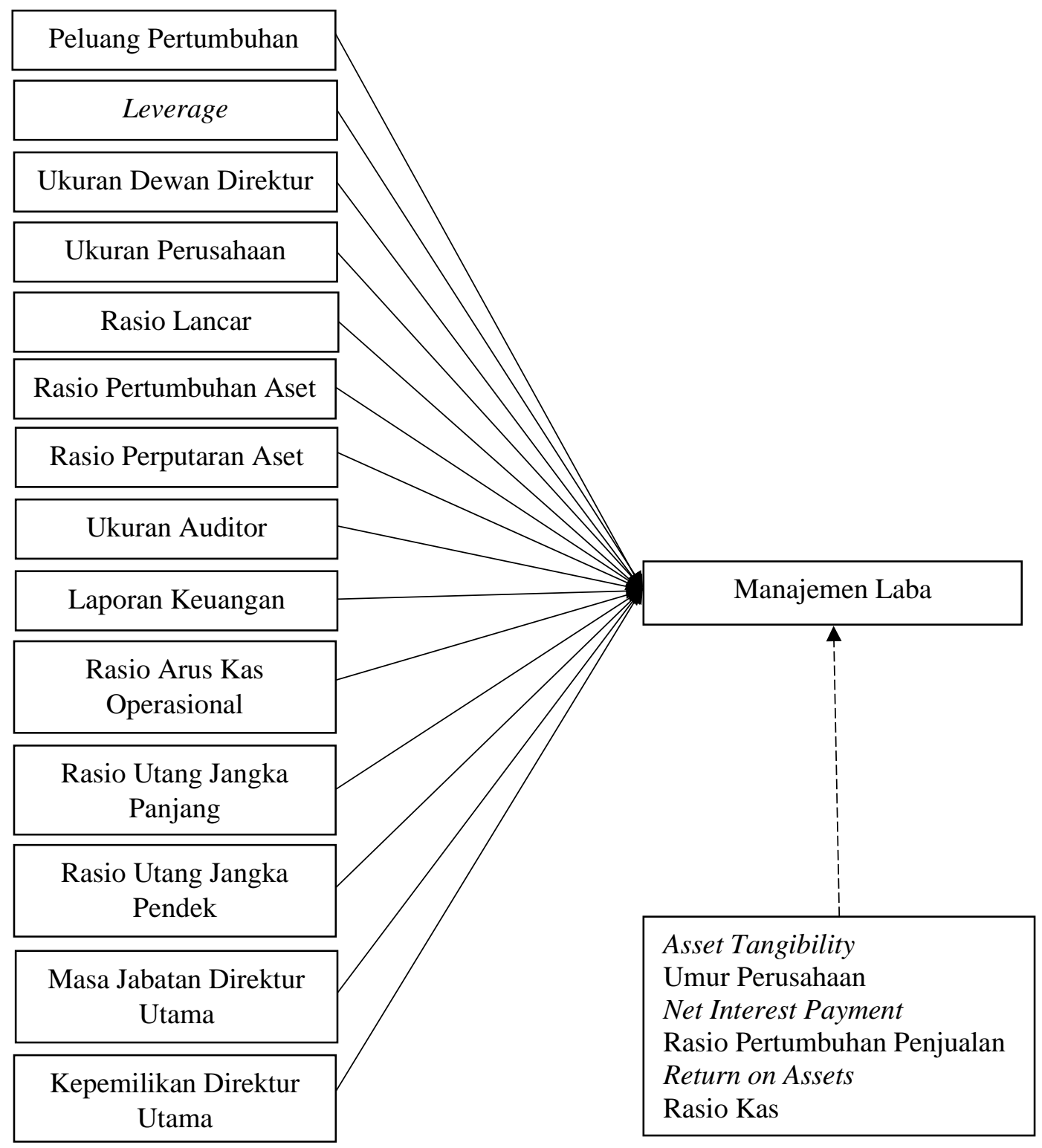

Gambar 1. Kerangka Penelitian

\section{METODE PENELITIAN}

Pada penelitian ini data yang digunakan adalah data sekunder sehingga teknik pengumpulan data berupa data yang diambil dari laporan keuangan perusahaan terbuka yang terdaftar di Bursa Efek Indonesia (BEI) sehingga laporan tahunan dapat dilihat pada website 
www.idx.co.id. Objek penelitian diambil dengan teknik purposive sampling sehingga memiliki kriteria tertentu. Kriteria tersebut adalah perusahaan bukan merupakan perusahaan di bidang keuangan atau financial dan perusahaan mempublikasikan laporan keuangan atau tahunan lengkap 5 tahun (2015-2019). Jumlah perusahaan yang memenuhi kriteria berjumlah 399 perusahaan dikalikan dengan periode penelitian sehingga menjadi 1.995 data perusahaan yang akan diuji.

Penelitian ini menggunakan uji regresi data panel yang dikarenakan merupakan data bersifat kuantitatif dan menggunakan jangka waktu tertentu yaitu lima tahun (2015-2019), sehingga pengujian data akan dilakukan dengan menggunakan dua program yaitu program SPSS 25 dan Eviews 10. Program SPSS akan digunakan untuk menguji hasil deskriptif statistika dan program Eviews digunakan untuk menguji data dengan pendekatan fixed effect model.

Variabel dependen pada penelitian ini adalah manajemen laba. Model perhitungan untuk manajemen laba akan menggunakan model Modified Jones dari penelitian Dechow et al. (1995) dikarenakan pada rumus ini ada menggunakan perubahan piutang pelanggan yang dapat menghapuskan pengaruh dari laba akrual yang bisa saja disebabkan oleh peningkatan piutang pada periode tersebut. Sehingga perubahan laba akan lebih akurat dan menampilkan lingkup bisnis perusahaan pada tahun tersebut (Cuong \& Ha, 2018).

Menurut penelitian Dechow et al. (1995), variabel discretionary accruals (DA) yang merupakan kumulatif yang dapat disesuaikan dapat menunjukan manipulasi laba perusahaan dengan rumus berikut ini.

$D A \quad=T A-N D A$

Keterangan:

DA = Discretionary acruals,

TA = Jumlah akrual yang didefinisikan sebagai pengurangan dari laba setelah pajak dengan arus kas operasional,

NDA = Non-discretionary accruals .

NDA atau non discretionary accruals yang dibentuk berdasarkan peraturan dan regulasi sistem serta standar akuntansi. Perhitungan NDA berdasarkan model Dechow et al. (1995) adalah sebagai berikut.

$\frac{N D A_{t}}{A_{t-1}} \quad=\alpha \frac{1}{A_{t-1}}+\beta_{1} \frac{\left(\triangle R E V_{t}-\Delta R E C_{t}\right)}{A_{t-1}}+\beta_{2} \frac{P P E_{t}}{A_{t-1}}$

Keterangan:

$A_{t-1}=$ Jumlah aset perusahaan pada periode sebelumnya,

$\triangle R E V_{t}=$ Selisih laba perusahaan dengan periode sebelumnya,

$\triangle R E C_{t}=$ Selisih piutang perusahaan dengan periode sebelumnya,

$P P E_{t} \quad=$ Aset tetap perusahaan pada periode tersebut.

Seluruh variabel dalam persamaan tersebut dibagi dengan A_(t-1) untuk meminimalisir risiko varians heterogen. Maka, rumus akhir untuk mengukur manajemen laba yang juga digunakan dalam penelitian Cuong \& Ha (2018), Edi \& Jessica (2020), Hung et al. (2018) adalah sebagai berikut. 


$$
M L=\frac{T A_{t}}{A_{t-1}}-\left(a_{1} \frac{1}{A_{t-1}}+a_{2} \frac{\left(\triangle R E V_{t}-\triangle R E C_{t}\right)}{A_{t-1}}+a_{3} \frac{P P E_{t}}{A_{t-1}}\right)
$$

Variabel independen pada penelitian ini ada tiga yaitu karakteristik perusahaan, kinerja perusahaan, dan management entrenchment. Karakteristik perusahaan berperan penting bagi perusahaan sebagai penilai kinerja perusahaan. Dalam penelitian ini beberapa variabel yang diambil dari penelitian pendukung dikelompokan menjadi topik karakteristik perusahaan karena variabel tersebut menunjukan ciri-ciri dari perusahaan tersebut dari segi perjalanan bisnis perusahaan saat ini maupun peluang bagi masa depan.

Peluang pertumbuhan perusahaan merupakan hal yang dapat menentukan kemampuan perusahaan untuk menghasilkan laba seiring dengan pertumbuhan perusahaan tersebut sehingga investor memandangnya penting. Dalam penelitian ini peluang pertumbuhan perusahaan diukur dengan menggunakan market to book ratio dengan persamaan yang sesuai penelitian Nguyen (2020) dan Trung et al. (2020) yaitu.

$$
\text { Peluang Pertumbuhan }=\frac{\text { Harga Saham }}{\text { Harga Buku per Saham }}
$$

Fungsi dari rasio tersebut adalah membantu investor untuk menentukan apakah nilai saham perusahaan undervalued atau overvalued. Selanjutnya, leverage diukur dengan persamaan rasio seperti pada penelitian Daghsni et al. (2016), Alexander \& Hengky (2017), Ghazali et al. (2015) dan Gunawan et al. (2015) seperti berikut ini.

$$
\text { Leverage }=\frac{\text { Jumlah Liabilitas }}{\text { Jumlah Aset }}
$$

Ukuran dewan direktur diukur dengan jumlah dewan direktur seperti pada penelitian Aygun et al. (2014), Swastika (2013), dan Iraya, Mwangi, \& Muchoki (2015). Ukuran perusahaan diukur dengan natural logaritma jumlah aset perusahaan seperti penelitian Ali et al. (2015), Edi \& Jessica (2020), dan Ghazali et al. (2015). Kemudian rasio lancar dimana semakin tinggi hasil rasio ini maka akan semakin tinggi pula kemampuan perusahaan untuk membayarkan utang jangka pendeknya pada tepat waktu. Rasio lancar diukur dengan rumus yang didasari dari penelitian Adi et al. (2020) dan Cuong \& Ha (2018).

$$
\text { Rasio lancar }=\frac{\text { Aset Lancar }}{\text { Liabilitas Lancar }}
$$

Aset yang telah menjadi elemen terpenting dalam perusahaan selain dianalisis dengan ukuran perusahaan, juga dapat dianalisis dengan 2 rasio yaitu pertumbuhan aset dan perputaran aset sebagai penentuan bagaimana perusahaan memberdayakan aset untuk mempertahankan kelangsungan operasional serta kefektifannya dalam menghasilkan penjualan. Pengukuran rasio pertumbuhan aset telah digunakan oleh Debnath (2017) dan Jang \& Kim (2017) dengan rumus.

$$
\text { Rasio Pertumbuhan Aset }=\frac{\text { (Jumlah Aset } \left.- \text { Jumlah Aset }{ }_{t-1}\right)}{\text { Jumlah Aset }_{t-1}}
$$

Rasio perputaran aset menggunakan pengukuran pada penelitian Adi et al. (2020) dan Cuong \& Ha (2018) dengan rumus:

$$
\text { Rasio Perputaran Aset }=\frac{\text { Penjualan }}{\text { Jumlah Aset }}
$$


Ukuran auditor dan laporan keuangan yang merupakan variabel dummy diukur dengan nilai angka 1 dan 0 . Ketika perusahaan menggunakan auditor eksternal yang berafiliasi dengan BIG 4 (KPMG, Deloitte, Ernest \& Young, dan PwC), maka menggunakan nilai 1 dan 0 jika tidak berafiliasi. Pengukuran ukuran auditor didasari oleh penelitian (Edi \& Jessica, 2020; Fung \& Goodwin, 2013; Park, 2016) Sedangkan laporan keuangan diukur dengan nilai 1 jika laporan keuangan perusahaan merupakan laporan konsolidasian dan 0 jika sebaliknya.

Kemudian kinerja perusahaan dijabarkan menjadi tiga variabel yaitu arus kas operasional, utang jangka panjang, dan utang jangka pendek. Arus kas operasional merupakan salah satu indikator bagi pembaca untuk menilai apakah perusahaan tersebut menghasilkan laba melalui kegiatan operasionalnya. Sehingga mengikuti perhitungan di penelitian yang telah ada, didapatkan rumusnya sebagai berikut (Cuong \& Ha, 2018; Jang \& Kim, 2017).

$$
\text { Rasio Arus Kas Operasional }=\frac{\text { Arus Kas Operasional }}{\text { Jumlah Aset }_{t-1}}
$$

Utang jangka panjang dihitung menggunakan rasio utang jangka panjang terhadap total aset yang dapat memberitahukan pembaca bagaimana kemampuan perusahaan dalam mencairkan asetnya untuk menutupi liabilitas jangka panjangnya. Berdasarkan penelitian Christiawan \& Rahmiati (2015), Cuong \& Ha (2018), dan Tulcanaza-Prieto et al. (2020), utang jangka panjang dihitung menggunakan persamaan sebagai berikut.

$$
\text { Rasio Utang Jangka Panjang }=\frac{\text { Utang Jangka Panjang }}{\text { Jumlah Aset }}
$$

Variabel independen yang terakhir pada kinerja perusahaan adalah utang jangka pendek dengan menggunakan pengukuran rasio utang jangka pendek terhadap jumlah liabilitas. Perusahaan yang menggunakan peminjaman jangka pendek dapat menurunkan biaya yang dikeluarkan dari perusahaan dibanding dengan peminjaman jangka panjang. Persamaan dari pengukuran tersebut sesuai penelitian Fung \& Goodwin (2013), Park (2016), Trung et al. (2020) dan Nguyen (2020) sebagai berikut.

$$
\text { Rasio Utang Jangka Pendek }=\frac{\text { Utang Jangka Pendek }}{\text { Jumlah Liabilitias }}
$$

Management entrenchment dijabarkan menjadi dua variabel yang berpatokan pada direktur utama perusahaan yaitu masa jabatan direktur utama dan kepemilikan saham direktur utama. Masa jabatan direktur utama diukur dengan jumlah tahun direktur utama menjabat jabatannya seperti pada penelitian Alhmood et al. (2020), Hu, Hao, Liu, \& Yao (2015), dan Qawasmeh \& Azzam (2020). Kepemilikan saham direktur utama diukur dengan persentase saham yang dimiliki oleh direktur utama. Pengukuran tersebut dilandasi dari penelitian Fagbemi et al. (2020) dan Qawasmeh \& Azzam (2020).

Variabel kontrol adalah variabel independen lainnya yang dapat memberikan pemahaman lebih jelas tentang peran variabel independen pada variabel dependen. Dalam penelitian ini ada enam variabel kontrol yaitu asset tangibility, umur perusahaan, net interest payment, pertumbuhan penjualan, return on assets dan kas. Asset tangibility diukur dengan membagikan aset tetap pada jumlah aset (Tulcanaza-Prieto et al., 2020). Umur perusahaan diukur dengan jumlah tahun perusahaan tersebut telah berjalan (Alhmood et al., 2020; Qawasmeh \& Azzam, 2020). Net interest 
payment diukur menggunakan rumus yang telah digunakan dalam penelitian Tulcanaza-Prieto et al. (2020) yaitu sebagai berikut.

$$
\text { Net Interest Payment }=\frac{(\text { Pendapatan Bunga }- \text { Beban Bunga })}{\text { Jumlah Aset }}
$$

Pertumbuhan penjualan diukur dengan membagikan perubahan penjualan dua tahun dengan penjualan tahun sebelumnya (Alhmood et al., 2020; Asim \& Ismail, 2019; Hu et al., 2015). Return on assets diukur dengan persamaan seperti dari penelitian Aygun et al. (2014), Cuong \& Ha (2018), dan Qawasmeh \& Azzam (2020).

$$
\text { Return on Assets }=\frac{\text { Laba Tahun Berjalan }}{\text { Jumlah Aset }}
$$

Return on assets yang tinggi memiliki arti perusahaan menghasilkan uang yang lebih banyak dengan investasi yang rendah. Maka, melalui return on assets investor dapat menilai seberapa efektif suatu perusahaan ketika menukarkan uang yang telah diinvestasikan menjadi pendapatan neto.

Kas diukur dengan menjumlahkan kas dan kas ekuivalen kemudian dibagi dengan jumlah aset perusahaan.

$$
\text { Rasio Kas }=\frac{\text { Kas dan Setara Kas }}{\text { Jumlah Aset }}
$$

Persamaan diatas merupakan persamaan yang telah digunakan dalam penelitian Nguyen (2020), Trung et al. (2020), dan Uwuigbe et al. (2015). Perhitungan tersebut disarankan untuk memiliki rasio satu banding satu. Ketika rasio tersebut tinggi menunjukan perusahaan menyimpan terlalu banyak kas atau memiliki kemampuan menagih piutang yang rendah. Namun, ketika rasio rendah bisa saja mengindikasi perusahaan terlalu bergantungan pada persediaan untuk mencapai obligasinya.

\section{HASIL DAN PEMBAHASAN}

Tabel 1 menunjukan bahwa berdasarkan hasil adjusted $r$-squared yang mengindikasikan persentase variabel independen dan kontrol dalam penelitian ini dapat menjelaskan variabel dependennya. Dengan nilai 0,640667 , berarti model penelitian ini dapat menjelaskan variabel dependen yaitu manajemen laba sebesar $64,07 \%$. Sedangkan $F$-statistic menunjukan nilai 0,0000 yang mengindikasikan variabel independen dan kontrol pada penelitian ini berpengaruh secara simultan terhadap manajemen laba. Selain itu, Tabel 1 juga menunjukan hasil uji yang dapat membuktikan apakah hipotesis penelitian ini diterima atau tidak. 
Tabel 1. Hasil Uji Regresi Data Panel

\begin{tabular}{lrrrr}
\hline Variabel & \multicolumn{1}{c}{ Coef. } & $\begin{array}{c}\text { Std. } \\
\text { Error }\end{array}$ & t-Statistic & Prob. \\
\hline Const. & 3,6901 & 0,8285 & 4,4540 & 0,0000 \\
PP & 0,0000 & 0,0000 & $-1,6736$ & 0,0944 \\
LEV & $-0,0663$ & 0,0312 & $-2,1226$ & 0,0339 \\
UDD & $-0,0042$ & 0,0109 & $-0,3880$ & 0,6980 \\
UP & $-0,1362$ & 0,0278 & $-4,8899$ & 0,0000 \\
RL & 0,0000 & 0,0001 & $-0,2357$ & 0,8137 \\
PTA & $-0,0849$ & 0,0150 & $-5,6675$ & 0,0000 \\
PPA & $-0,4671$ & 0,0246 & $-18,9789$ & 0,0000 \\
UA & 0,0580 & 0,1120 & 0,5175 & 0,6049 \\
LK & 0,3813 & 0,3396 & 1,1226 & 0,2618 \\
AKO & $-0,7675$ & 0,0980 & $-7,8328$ & 0,0000 \\
JPA & 0,2203 & 0,0583 & 3,7801 & 0,0002 \\
JPE & 0,2072 & 0,0692 & 2,9918 & 0,0028 \\
MJD & 0,0086 & 0,0025 & 3,4181 & 0,0006 \\
KDU & $-0,0970$ & 0,2334 & $-0,4155$ & 0,6778 \\
AT & $-1,2125$ & 0,0593 & $-20,4470$ & 0,0000 \\
UMP & 0,0009 & 0,0052 & 0,1730 & 0,8627 \\
NIP & $-2,5779$ & 0,3330 & $-7,7423$ & 0,0000 \\
PTP & $-0,0095$ & 0,0026 & $-3,6382$ & 0,0003 \\
ROA & 0,1070 & 0,0390 & 2,7468 & 0,0061 \\
KAS & $-0,1565$ & 0,1407 & $-1,1118$ & 0,2664 \\
\hline Adjusted $R$-Squared & 0,640667 & & \\
Prob(F-statistic) & 0,000000 & & \\
\hline \hline
\end{tabular}

Berdasarkan data pada Tabel 1 menunjukan bahwa peluang pertumbuhan tidak mempengaruhi potensi terjadinya manajemen laba, sehingga ketika saham perusahaan overvalued ataupun undervalued tidak memicu manajemen untuk melakukan penipuan. Hasil ini selaras dengan penelitian Qawasmeh \& Azzam (2020) dan Surya (2017). Namun, hasil menunjukan hipotesis pertama dimana peluang pertumbuhan memiliki pengaruh signifikan positif tidak sesuai. Hal ini dapat terjadi dikarenakan perbedaan pada negara perusahaan yang diteliti, sehingga memiliki hasil yang berbeda. Leverage menunjukan pengaruh signifikan negatif maka ketika tingkat resiko perusahaan tinggi, hal tersebut justru menurunkan potensi akan terjadinya penipuan informasi dalam laporan keuangan. Hasil ini selaras dengan hasil penelitian Edi \& Jessica (2020) dan Trung et al. (2020). Maka dari itu, hipotesis kedua tidak diterima karena diperkirakan ketika leverage tinggi maka resiko yang tinggi dapat memicu perlakuan penipuan ini. Namun, hasil menunjukan hal yang berbanding terbalik.

Ukuran dewan direktur tidak memiliki pengaruh signifikan terhadap manajemen laba, sehingga menolak hipotesis ketiga dimana penelitian terdahulu mayoritas memiliki hasil signifikan negatif. Namun, hasil ini selaras dengan penelitian Edi \& Jessica (2020) yang menggunakan sampel negara yang sama. Ukuran perusahaan memiliki pengaruh signifikan negatif terhadap manajemen laba sehingga semakin besar perusahaan dengan transaksi dan operasional yang banyak justru memicu manajemen untuk melakukan manipulasi laba seperti dengan mengurangi biaya pajak. Maka, hipotesis 4 diterima dan selaras dengan penelitian Mahawyahrti \& Budiasih (2017) dan Tulcanaza-Prieto et al. (2020). Rasio lancar memiliki hasil yang tidak signifikan, sehingga kemampuan perusahaan dalam membayar utang lancarnya tidak mempengaruhi keputusan manajemen untuk mencoba melakukan manipulasi laba. Hasil ini menolak hipotesis 
kelima yang memprediksikan adanya pengaruh signifikan negatif dan belum ada penelitian terdahulu yang mendapatkan hasil tidak signifikan.

Rasio pertumbuhan aset memiliki pengaruh signifikan negatif terhadap manajemen laba. Hasil tersebut menolak hipotesis enam yang memprediksikan adanya pengaruh signifikan positif. Sehingga diasumsikan bahwa ketika perusahaan memiliki pertumbuhan aset yang rendah, manajemen akan berusaha untuk mengubah informasi tersebut yang dapat meningkatkan persentase pertumbuhan perusahaan agar dapat dinilai baik di mata pengguna laporan. Perusahaan yang memiliki aset yang semakin tinggi dibanding periode sebelumnya dinilai memiliki kemampuan mempertahankan kelangsungan operasionalnya sehingga manajemen tidak perlu melakukan manipulasi laba.

Berdasarkan hasil uji, perputaran aset memiliki pengaruh signifikan negatif yang sesuai dengan hipotesis tujuh. Dengan aset yang tinggi, perusahaan juga harus dapat menggunakan asetnya untuk menciptakan penjualan supaya memiliki tingkat efisiensi penggunaan set yang baik. Sehingga ketika efisiensi penggunaan aset perusahaan tinggi, manajemen juga tidak memiliki alasan untuk melakukan manipulasi. Ukuran auditor ditemukan tidak ada pengaruh signifikan sehingga menolak hipotesis delapan. Auditor yang digunakan oleh perusahaan tidak menjamin kualitas audit dan juga tidak mempengaruhi keinginan manajemen untuk memanipulasi laporan perusahaan. Begitu pula untuk laporan keuangan, tidak memiliki pengaruh signifikan dan menolak hipotesis sembilan yang seharusnya memiliki pengaruh signifikan positif. Hasil ini belum didukung oleh penelitian terdahulu dikarenakan belum banyak penelitian yang meneliti variabel ini sehingga memiliki keterbatasan. Laporan keuangan konsolidasian maupun laporan keuangan tunggal tidak mempengaruhi ataupun memicu manajemen untuk melakukan manipulasi laba.

Kinerja perusahaan yang diukur melalui arus kas operasional, utang jangka panjang, dan utang jangka pendek memiliki hasil yang sesuai dengan hipotesis. Arus kas operasional menunjukan jika perusahaan menghasilkan arus kas operasional yang semakin tinggi maka tingkat terjadinya manajemen laba akan menurun. Maka hasil ini sesuai dengan hipotesis 10 dan sesuai dengan hasil penelitian terdahulu Park (2016), Cuong \& Ha (2018), Hapsoro \& Annisa (2017), dan Jang \& Kim (2017). Hipotesis 11 diterima dengan adanya pengaruh signifikan positif dari utang jangka panjang. Sehingga ketika perusahaan memiliki utang jangka panjang memicu manajemen yang semakin tinggi motivasinya untuk mengubah informasi sebenarnya dengan menurunkan jumlah utang jangka panjang daripada angka yang sebenarnya. Hasil ini sesuai dengan penelitian terdahulu Christiawan \& Rahmiati (2015) dan Tulcanaza-Prieto et al. (2020).

Utang jangka pendek juga menunjukan hasil sesuai dengan hipotesis 12 dimana memiliki pengaruh signifikan positif terhadap manajemen laba. Utang jangka pendek yang tinggi dapat meningkatkan risiko likuiditas perusahaan sehingga dapat dipandang sebagai hal yang tidak baik bagi pengguna laporan sehingga ketika perusahaan memiliki risiko likuiditas yang tinggi, manajemen akan berusaha untuk menurunkan angka utang jangka pendek agar kinerja perusahaan dapat dipandang masih bagus. Hasil ini sesuai dengan penelitian terdahulu oleh Fung \& Goodwin (2013), Park (2016), dan Trung et al. (2020).

Management entrenchment yang diukur melalui masa jabatan direktur utama dan kepemilikan saham direktur utama memiliki hasil yang sesuai dengan hipotesis 13 dan menolak hipotesis 14. Masa jabatan direktur utama memiliki probabilitas <0,05 dan koefisien sebesar 0,0086 yang menunjukan bahwa ketika direktur utama perusahaan telah menjabati jabatan semakin 
lama, maka semakin mungkin akan melakukan manipulasi seiring berjalannya masa jabatan yang ia miliki. Hasil ini sesuai dengan penelitian Fagbemi et al. (2020) dan Qawasmeh \& Azzam (2020). Sedangkan hipotesis 14 yang mengasumsikan akan ada pengaruh signifikan ternyata tidak terbukti. Dari Tabel 1 terlihat bahwa probabilitas kepemilikan direktur utama $>0,05$ sehingga dinyatakan tidak berpengaruh secara signifikan terhadap manajemen laba. Hal ini selaras dengan penelitian Fagbemi et al. (2020).

Variabel kontrol dalam penelitian ini yang terdiri asset tangibility, net interest payment, dan pertumbuhan penjualan menunjukan bahwa memiliki pengaruh secara signifikan negatif terhadap manajemen laba sedangkan return on assets berpengaruh secara signifikan positif terhadap manajemen laba. Ketika perusahaan memiliki persentase aset tetap yang semakin besar dibandingkan jumlah aset perusahaan maka manajemen tidak akan muncul niat untuk melakukan manipulasi laporan keuangannya. Net interest payment yang menunjukan hasil signifikan negatif berarti ketika perusahaan memiliki pendapatan bunga yang lebih besar daripada beban bunga tidak akan memicu manajemen untuk melakukan manipulasi. Namun, jika kebalikannya terjadi dimana perusahaan memiliki beban bunga yang sama jumlahnya atau lebih besar daripada beban bunga dapat memicu manajemen untuk mengubah informasi tersebut agar laporan perusahaan terlihat memiliki pendapatan yang lebih tinggi dibanding bebannya.

Pertumbuhan penjualan menunjukan hasil signifikan negatif dimana ketika perusahaan memiliki penjualan yang lebih tinggi dibandingkan periode sebelumnya tidak akan memicu manajemen untuk melakukan penipuan informasi keuangan. Return on assets memiliki pengaruh signifikan positif sehingga ketika perusahaan memiliki return on assets yang tinggi maka dapat memicu manajemen untuk melakukan manipulasi laba. Hal tersebut dikarenakan return on assets yang tinggi mengartikan perusahaan kurang efektif dalam memberdayakan asetnya untuk menghasilkan laba. Umur perusahaan dan rasio kas ditampilkan pada Tabel 1 dengan hasil tidak signifikan karena memiliki probabilitas $>0,05$. Sehingga kedua variabel tersebut tidak dapat dijadikan sebagai faktor yang mempengaruhi keputusan dan keinginan manajemen dalam melakukan manipulasi.

\section{SIMPULAN DAN REKOMENDASI}

Berdasarkan hasil uji dalam pembahasan, disimpulkan bahwa peluang pertumbuhan perusahaan, ukuran dewan direktur, rasio lancar, ukuran auditor, laporan keuangan, dan kepemilikan direktur utama tidak mempengaruhi potensi terjadinya manajemen laba. Sedangkan leverage, ukuran perusahaan, pertumbuhan aset dan perputaran aset, dan arus kas operasional memiliki pengaruh signifikan negatif. Utang jangka panjang, utang jangka pendek, dan masa jabatan direktur utama berpengaruh signifikan positif. Sehingga dapat disimpulkan dari ketiga topik variabel yang diteliti secara keseluruhan, karakteristik perusahaan memiliki hubungan signifikan negatif terhadap manajemen laba dimana ketika perusahaan memiliki aset yang semakin banyak jumlahnya dapat mengurangi potensi terjadinya manajemen laba. Sedangkan kinerja perusahaan secara keseluruhan memiliki pengaruh signifikan positif sehingga ketika perusahaan memiliki tingkat pinjaman atau utang yang semakin tinggi, maka akan semakin tinggi pula motivasi dalam menerapkan manajemen laba. Management entrenchment yang terdiri dari dua variabel memiliki pengaruh yang berbeda, dimana semakin lama direktur utama menjabat dalam suatu perusahaan maka semakin tinggi pula tingkat akan terjadinya manajemen laba. Namun, 
ketika direktur utama memiliki saham perusahaan yang banyak maupun sedikit, tidak memberikan motivasi untuk melakukan manajemen laba.

Hasil yang menunjukan beberapa variabel tidak berpengaruh secara signifikan terhadap manajemen laba dapat terjadi akibat dari keterbatasan atau limitasi dalam penelitian seperti keterbatasan periode dengan jangka waktu lima tahun dan banyaknya model pengukuran variabel manajemen laba seperti model Jones dan model yang telah dimodifikasi. Sehingga saran untuk peneliti selanjutnya, diharapkan dapat menelaah lebih dalam terkait unsur perusahaan yang bisa menjadi faktor pemicu, memperpanjang jangka waktu periode penelitian supaya mendapatkan hasil yang lebih akurat atau dapat menggunakan metode pengukuran yang berbeda, serta melibatkan variabel lain agar meningkatkan persentase keakuratan pengaruh variabel.

\section{DAFTAR PUSTAKA}

Adi, S. W., Putri, W. A. P., \& Permatasari, W. D. (2020). Profitability, Leverage, Firm Size, Liquidity, and Total Assets Turnover on Real Earnings Management (An Empirical Study on the Mining Company Classification Registered at Indonesia Stock Exchange (IDX) 2014-2017). Riset Akuntansi dan Keuangan Indonesia, 5(2), 129-140. https://doi.org/10.23917/reaksi.v5i2.12403

Agustia, D. (2013). Pengaruh Faktor Good Corporate Governance, Free Cash Flow, dan Leverage Terhadap Manajemen Laba. Jurnal Akuntansi dan Keuangan, 15(1), 27-42. https://doi.org/10.9744/jak.15.1.27-42

Alexander, N., \& Hengky. (2017). Factors Affecting Earnings Management in the Indonesian Stock Exchange. Journal of Finance and Banking Review, 2(2), 8-14. www.gatrenterprise.com/GATRJournals/index.html

Alhmood, M. A., Shaari, H., \& Al-dhamari, R. (2020). CEO Characteristics and Real Earnings Management in Jordan. International Journal of Financial Research, 11(4), 255-266. https://doi.org/10.5430/ijfr.v11n4p255

Ali, U., Khurshid, M. K., \& Mahmood, A. (2015). Impact of Firm Size on Earnings Management: A Study of Textile Sector of Pakistan. SSRN Electronic Journal, 7(28), 47-56. https://doi.org/10.2139/ssrn.2698317

Arieza, U. (2019). Menyoal Laba BUMN yang Mendadak Kinclong. CNN Indonesia. Diakses dari 16 Januari 2021. https://www.cnnindonesia.com/ekonomi/20190531144248-92400048/menyoal-laba-bumn-yang-mendadak-kinclong

Asim, A., \& Ismail, A. (2019). Impact of Leverage on Earning Management: Empirical Evidence from the Manufacturing Sector of Pakistan. Journal of Finance and Accounting Research, 01(01), 70-91. https://doi.org/10.32350/jfar.0101.05

Aygun, M., Ic, S., \& Sayim, M. (2014). The Effects of Corporate Ownership Structure and Board Size on Earnings Management: Evidence from Turkey. International Journal of Business and Management, 9(12), 123-132. https://doi.org/10.5539/ijbm.v9n12p123

Bassiouny, S. W. (2018). The Impact of Firm Characteristics on Earnings Management: An Empirical Study on The Listed Firms in Egypt. Journal of Business and Retail Management Research, 10(3), 232-241. https://doi.org/10.24052/jbrmr/v12is02/tioccoeidaesotlfie

Christiawan, Y. J., \& Rahmiati, A. (2015). Earnings Management of Firms Reporting Long Term Debt: An Alternative Method. Jurnal Akuntansi dan Keuangan, 16(2), 113-120. https://doi.org/10.9744/jak.16.2.113-120 
Cuong, N., \& Ha, N. (2018). Influence of Financial Ratios on Earnings Management: Evidence from Vietnam Stock Exchange Market. Journal of Insurance and Financial Management, $4(1), 57-77$.

Daghsni, O., Zouhayer, M., \& Mbarek, K. B. H. (2016). Earnings Management and Board Characteristics: Evidence from French Listed Firms. Arabian Journal of Business and Management Review, 6(5), 1-9. https://doi.org/10.4172/2223-5833.1000249

Dang, N. H., Hoang, T. V. H., \& Tran, M. D. (2017). Factors Affecting Earnings Management: The Case of Listed Firms in Vietnam. International Journal of Economic Research, 14(20), 117-134.

Debnath, P. (2017). Assaying the Impact of Firm's Growth and Performance on Earnings Management: An Empirical Observation of Indian Economy. International Journal of Research in Business Studies and Management, 4(2), 30-40. https://doi.org/10.22259/ijrbsm.0402003

Dechow, P. M., Sloan, R. G., \& Sweeney, A. P. (1995). Detecting Earnings Management. The Accounting Review, 70(2), 193-225. https://doi.org/10.5694/j.13265377.1952.tb109167.x

Dong, G. N. (2016). Earnings management in U.S. hospitals. Journal of Health and Human Services Administration, 39(1), 41-71. www.jstor.org/stable/43948715

Edi \& Jessica, V. (2020). The Effect of Firm Characteristics and Good Corporate Governance Characteristics to Earning Management Behaviors. Journal of Accounting Finance and Auditing Studies (JAFAS), 6(2), 31-49. https://doi.org/10.32602/jafas.2020.009

Fagbemi, T. O., Osemene, O. F., \& Agbaje, O. (2020). Management Entrenchment, Firm Characteristics and Earnings Management of Conglomerate Companies In Nigeria. Jurnal Administrasi Bisnis, 9(1), 1. https://doi.org/10.14710/jab.v9i1.28576

Fung, S. Y. K., \& Goodwin, J. (2013). Short-Term Debt Maturity, Monitoring and Accruals-Based Earnings Management. Journal of Contemporary Accounting and Economics, 9(1), 67-82. https://doi.org/10.1016/j.jcae.2013.01.002

Ghazali, A. W., Shafie, N. A., \& Sanusi, Z. M. (2015). Earnings Management: An Analysis of Opportunistic Behaviour, Monitoring Mechanism and Financial Distress. Procedia Economics and Finance, 28(April), 190-201. https://doi.org/10.1016/s22125671(15)01100-4

Gunawan, I. K., Darmawan, N. A. S., \& Purnamawati, I. G. A. (2015). Pengaruh Ukuran Perusahaan, Profitabilitas, dan Leverage Terhadap Manajemen Laba. Jurnal Akuntansi Program S1 Universitas Pendidikan Ganesha, 03(1).

Hapsoro, D., \& Annisa, A. A. (2017). Pengaruh Kualitas Audit, Leverage, dan Growth Terhadap Praktik Manajemen Laba. Jurnal Akuntansi, 5(2), 99-110. https://doi.org/10.24964/ja.v5i2.272

Hu, N., Hao, Q., Liu, L., \& Yao, L. J. (2015). Managerial tenure and earnings management. International Journal of Accounting and Information Management, 23(1), 42-59. https://doi.org/10.1108/IJAIM-04-2014-0025

Hung, D. N., Linh, D. H., Hoa, T. T. Van, Dung, T. M., \& Ha, H. T. V. (2018). Factors Influencing Accrual Earnings Management and Real Earnings Management: The Case of Vietnam. Proceedings of 14th International Conference on Humanities and Social Sciences 2018 (IC-HUSO 2018) 22nd-23rd November 2018, Faculty of Humanities and Social Sciences, Khon Kaen University, Thailand, 2018(November), 1346-1363. 
Iraya, C., Mwangi, M., \& Muchoki, G. (2015). The Effect of Corporate Governance Practices on Earnings Management of Company Listed at The Nairobi Securities Exchange. European Scientific Journal, 11(1), 169-178.

Jang, G. B., \& Kim, W. J. (2017). Effects of Key Financial Indicators on Earnings Management in Korea's Ready Mixed Concrete Industry. Journal of Applied Business Research, 33(2), 329-342. https://doi.org/10.19030/jabr.v33i2.9905

Kankanamage, C. A. (2016). The Relationship Between Board Characteristics and Earnings Management: Evidence from Sri Lankan Listed Companies. Kelaniya Journal of Management, 4(2), 36. https://doi.org/10.4038/kjm.v4i2.7499

Mahawyahrti, T., \& Budiasih, G. N. (2017). Asimetri Informasi, Leverage, dan Ukuran Perusahaan pada Manajemen Laba. Jurnal Ilmiah Akuntansi dan Bisnis, 11(2), 100. https://doi.org/10.24843/jiab.2016.v11.i02.p05

Nguyen, L. (2020). Short Term Debt Maturity, Real Earnings Management and Firm Performance Short Term Debt Maturity, Real Earnings Management and Firm Performance. May.

Park, S. Y. (2016). The Effect of Short-Term Debt on Accrual Based Earnings Management and Real Earnings Management. Journal of Applied Business Research, 32(4), 1287-1300. https://doi.org/10.19030/jabr.v32i4.9737

Putri, S. E., \& Panggabean, R. R. (2020). The Effects of Corporate Governance, Firm Size, Profitability, and Growth Opportunities on The Value Relevance of Accounting Earnings - A Study of the Indonesia Stock Exchange. Ultimaccounting: Jurnal Ilmu Akuntansi, 12(2), 174-193. https://doi.org/10.31937/akuntansi.v12i2.1702

Qawasmeh, S. Y., \& Azzam, M. J. (2020). CEO Characteristics and Earnings Management. Accounting, 6(7), 1403-1410. https://doi.org/10.5267/j.ac.2020.8.009

Surya, B. J. M. H. (2017). Studi Pengaruh Short-Term Debt dan Earnings Management pada Badan Usaha yang Terdaftar di BEI dan Pefindo Tahun 2011-2013. Jurnal Ilmiah Mahasiswa Universitas Surabaya, 6(2).

Swastika, D. L. T. (2013). Corporate Governance, Firm Size, and Earning Management: Evidence in Indonesia Stock Exchange. IOSR Journal of Business and Management, 10(4), 77-82. https://doi.org/10.9790/487x-1047782

Trung, T. Q., Liem, N. T., \& Thuy, C. T. M. (2020). The Impact of Short-Term Debt on AccrualsBased Earnings Management-Evidence from Vietnam. Cogent Economics and Finance, 8(1). https://doi.org/10.1080/23322039.2020.1767851

Tulcanaza-Prieto, A. B., Lee, Y., \& Koo, J. H. (2020). Effect of Leverage on Real Earnings Management: Evidence from Korea. Sustainability (Switzerland), 12(6). https://doi.org/10.3390/su12062232

Uwuigbe, U., Ranti, U. O., \& Bernard, O. (2015). Assessment of The Effects. of Firms Characteristics on Earnings Management of Listed Firms in Nigeria. Asian Economic and Financial Review, 5(2), 218-228. https://doi.org/10.18488/journal.aefr/2015.5.2/102.2.218.228

Waweru, N. M., \& Riro, G. K. (2013). Corporate Governance , Firm Characteristics and Earnings Management in an Emerging Economy. Journal of Applied Management Accounting Research, 11(1), 43-64. 